Agro-Science Journal of Tropical Agriculture, Food, Environment and Extension Volume 20 Number 2 (April 2021) pp. $57-61$

ISSN 1119-7455

\title{
CREDIT ACCESS AND FAECAL MANAGEMENT PRACTICES AMONG POULTRY FARMERS IN OGUN STATE, NIGERIA: IMPLICATIONS FOR CLIMATE CHANGE
}

\author{
"Osuntade O.B. and Babalola D.A. \\ Department of Agriculture \& Industrial Technology, \\ Babcock University, Ilishan Remo, Ogun State, Nigeria \\ *Corresponding author's email: osuntadeo@babcock.edu.ng
}

\begin{abstract}
This research identified the sources of credit available and utilized by the respondents, evaluated the socioeconomic factors determining farmers' access to credit, constraints encountered by respondents and the influence of access to credit on management practices of poultry farmers in Obafemi Owode Local Government of Ogun State. The data collected from 90 poultry farmers were analyzed using descriptive statistics and the logit regression model, to evaluate the socio-economic factors determining the respondents' access to credit and also to analyze the influence of access to credit on faecal management practices in the study area. The descriptive result showed the farmers earned less than $\$ 100,000$ monthly (mean $=61,402 \pm 12,127.17$, ca. \$290) and up to $48 \%$ still lacked access to credit. The major use of credit among the farmers was for operational activities (53\%) which included waste management. Only $48 \%$ of the farmers had access to quality extension service and $46 \%$ do not participate in any cooperative. Despite the fact that most of the farmers were aware of impact of farming activities on climate change, about $80 \%$ still practiced open dumping of faecal waste without proper treatment because of credit constraint. The logit result (all at $p<0.05)$ showed that farming experience, farm size, awareness of credit source, cooperative participation, access to extension service and farm income were associated with both access to credit and farmers' use of appropriate waste management practice. Based on the findings, it is recommended that better waste management practices among poultry farmers should be enhanced by facilitating increased access to credit and this is sine qua non to mitigating climate change.
\end{abstract}

Key words: climate change, credit access, faecal management, Nigeria, poultry

\section{INTRODUCTION}

The poultry industry plays important roles in the development of Nigerian economy, contributing to the overall Gross Domestic Product (GDP) of the country and about 9-10 percent of the Agricultural GDP (Heise, 2015). The Nigerian poultry sub-sector is experiencing rapid growth and transformation. This is linked to the transformation of diets as incomes and urbanization increase. Poultry is both a protein and income source for many households and the poultry subsector in Nigeria is quite complex. Chicken importation (with the exception of day-oldchicks) was banned by Nigeria in 2003, which spurred growth in domestic poultry production with about 10 percent of the Nigerian population keeping poultry either in small or large scale (Sahel Capital, 2015) meaning that as the population increases, poultry production will also increase hence the need for more focus on the management practices especially for faecal waste and its impacts on the environment and the climate (Musa and Kaltungo, 2017). Generally, agriculture is a major contributor to greenhouse gas emission and livestock production contributes between 15 and $24 \%$ of global emission such as nitrogen oxide $\left(\mathrm{N}_{2} \mathrm{O}\right)$, ammonia $\left(\mathrm{NH}_{3}\right)$, carbon dioxide $\left(\mathrm{CO}_{2}\right)$ and methane $\left(\mathrm{CH}_{4}\right)$ (Musa and Kaltungo, 2017). These emissions result in climate change with secondary impact on human health, land degradation, increased frequency of fires, poverty and malnutrition (IPCC, 2019). This has a lot of policy implication especially in achieving the Sustainable Development Goals (SDGs).

The variability of climate also affects agricultural yield greatly. Thus, there is a bi-causal relationship between climate change and agricultural yield variability and this has been established in previous studies (Babalola et al., 2015; Adejuwom and Ogundiminegha, 2019). Ogun State is one of the agrarian belts in Nigeria that is especially known for poultry production. The state is also sensitive to climate variability, especially rainfall and temperature (Adejuwon and Ogundiminegha, 2019). Aiyelokun and Odekoya (2016) reported that these two climate elements have recorded significant increasing trend since the 1990s mostly due to greenhouse gasses. The growth of the poultry industry may further accelerate the growth trend if waste management is not taken seriously. 
The management of faecal waste constitutes a major challenge to the poultry industry in Nigeria with the use of waste to farm yard manure topping the list in most poultry farms in Nigeria (Onu et al., 2015; Baruwa and Omodara, 2018); the disposal method of poultry needs to meet several criteria including convenience, sanitary, economical, practical, legal, socially acceptable and environmentally friendly. Modern management strategies like green disposal, gasification and biogas production and composting have been recommended, bearing in mind climate change mitigation, but with low adoption rate among Nigerian farmers (Osuntade and Adebayo, 2019). The practice of Integrated Waste Management being practiced in other countries like Ghana is being referred to, as the most environmental friendly practice (McAllister, 2015), where community organizations and individual participations are mostly encouraged. Top on the list of their constraints to adoption of emerging and indigenous alternative waste management practices is the inability to finance the additional cost required for the technology involved. Access to credit facility is therefore pertinent in order to facilitate uptake of these environmentally friendly innovations (Osuntade and Adebayo, 2019).

The important role of credit in sustaining agribusiness has prompted the Federal Government of Nigeria to establish credit schemes and policies (Chioma et al., 2017). Despite these efforts, several poultry farmers are still credit constrained with great implication on their production efficiencies and waste management practices in fact less than 18 percent of farmers in Nigeria access credit from these formal sources (Oseni et al., 2019a). Low level of awareness and poor access to credit coupled with poor fund utilization and repayments have been posited as the major factors militating against the success of existing credit schemes (Isitor et al., 2014; Adeyonu, 2015; Jatto et al., 2019).

Ogun State's contribution to the poultry business has consistently been one of the largest in Nigeria (Osinowo and Tolorunju, 2019). It is plausible to infer that, with the steady growth of the poultry industry in Ogun State, there will be increased vulnerability to effects of climate change and a contagion effect on neighbouring vicinities, except quick efforts are taken to mitigate the effect.

This study accessed the factors influencing credit constraint and faecal management among poultry farmers in Ogun State, Nigeria and its implication for climate change. The study specifically identified the sources of credit available and utilized by the respondents, evaluated the socio-economic factors determining farmers' access to credit, constraints encountered by respondents and the influence of access to credit on management practices of poultry farmers in Obafemi Owode Local Government Area of Ogun State, Nigeria.

\section{MATERIALS AND METHODS}

The study was carried out in Obafemi Owode Local Government of Ogun State, Nigeria. This local government was selected based on its high contribution to poultry in the State. Primary data were collected with the help of well-structured questionnaire designed in line with study objectives. The respondents for the study were selected using the simple random sampling technique. Data from a total of 90 respondents were found useful for the analysis. Descriptive statistics and the logit regression model were used to analyze and present data. The choice of the logit model was because the dependent variable is qualitative (a dummy dependent variable) and because of its simplicity and wide use in research of this nature (Oseni et al., 2019a). Following Gujarati (1998), the model is specified as follows:

$$
\operatorname{Ln}\left(\mathrm{P}_{\mathrm{i}} /\left(1-\mathrm{P}_{\mathrm{i}}\right)=\beta_{0}+\beta_{\mathrm{i}} \mathrm{X}_{\mathrm{i}}+\ldots .+\beta_{\mathrm{n}} \mathrm{X}_{\mathrm{n}}+\mathrm{e} .\right.
$$

Equation 1 was used in accessing factors influencing both credit access and best management practice (BMP) in faecal disposal, where $\mathrm{P}_{1}$ is probability of farmer's access to credit for production, $1-\mathrm{P}_{1}$ is probability of no access to credit for production, $\mathrm{P}_{2}$ is probability of farmer's adopting $\mathrm{BMP}, 1-\mathrm{P}_{2}$ is probability of not adopting BMP, $\beta_{0}$ is intercept, $\beta_{i}(1,2,3 \ldots, 9)$ represent regression coefficients, $X_{i}$ $(1,2,3 \ldots, 9)$ represent independent variables, and $e_{i}$ is error term. The independent variables specified as factors influencing farmer's access to credit and probability of adopting BMP are defined as:

$\mathrm{X}_{1}=$ education (dummy: 1 = secondary to more than secondary education, $0=$ less than secondary education); $\mathrm{X}_{2}=$ farming experience (years); $\mathrm{X}_{3}=$ farm size (number of birds); $\mathrm{X}_{4}=$ awareness to credit source $($ Aware $=1$, Not aware $=0) ; X_{5}=$ cooperative membership ( $\mathrm{Yes}=1, \mathrm{No}=0) ; \mathrm{X}_{6}=$ distance to credit source $(\mathrm{km}) ; \mathrm{X}_{7}=$ system of bird keeping (dummy: $1=$ battery cage, $0=$ deep litter); $\mathrm{X}_{8}=$ access to extension service $(\mathrm{Yes}=1$, No $=0$ ); and $\mathrm{X}_{9}=$ farm income $(\mathrm{A})$.

\section{RESULTS AND DISCUSSION \\ Descriptive Result of Farmers' Personal Information and Waste Management}

Results in Table 1 show that the majority of the farmers in the study area were above 30 years old (mean $=38.8 \pm 8.2)$ and they are mostly male $(81 \%)$. The predominance of male farmers is an indication that agribusiness is generally labour intensive and still a strenuous enterprise in Nigeria. Furthermore, the tedious and time-consuming nature of the practices involved in poultry keeping discourages most prospective female entrances into the business. The majority of the respondents $(64 \%)$ had up to secondary education which shows considerable literacy level. This is expected to positively influence their adoption of innovations, best management practices (BMP) and utilization of credit. 
Table 1: Farmers' socio-economic characteristics

\begin{tabular}{|c|c|c|}
\hline Variables & $\begin{array}{l}\text { Percentage } \\
\text { (frequency) }\end{array}$ & Mean $( \pm \mathrm{SD})$ \\
\hline Married respondents & $91.1(82)$ & \\
\hline Gender: Male & $81.1(73)$ & \\
\hline Age (years) & & $38.8( \pm 8.2)$ \\
\hline Educational level: & & \\
\hline Primary & $4.45(4)$ & \\
\hline Secondary & $64.4(58)$ & \\
\hline Tertiary & $31.1(28)$ & \\
\hline Experience (years) & & $8.46( \pm 2.54)$ \\
\hline Participation in co-op & $54.4(49)$ & \\
\hline Access to quality ext. service & $47.8(43)$ & \\
\hline Household size: & & $4.82( \pm 1.18)$ \\
\hline Major housing system: & & \\
\hline Deep litter only & $58.9(53)$ & \\
\hline Battery cage only & $41.1(37)$ & \\
\hline Farm size (no. of birds): & & \\
\hline$<2000$ & $81.1(73)$ & \\
\hline$\geq 2000$ & $18.9(17)$ & \\
\hline Income per month & & \\
\hline$<50,000$ & $16.7(15)$ & \\
\hline $50,000-100,000$ & $58.9(53)$ & $\begin{array}{l}61,402 \\
( \pm 12,127.17)\end{array}$ \\
\hline$>100,000$ & $35.6(32)$ & \\
\hline $\begin{array}{l}\text { Access to credit } \\
\text { credit need: }\end{array}$ & $52.2(47)$ & \\
\hline Expansion of enterprise & $37.8(34)$ & \\
\hline Operational activities & $53.3(48)$ & \\
\hline None & $8.90(18)$ & \\
\hline Awareness of climate change & $91.1(82)$ & \\
\hline
\end{tabular}

Average household size was approximately 5 (4.82 \pm 1.18$)$. However, about $40 \%$ of the respondents have household size greater than 5 persons which is above the national average of approximately 6 persons (NBS, 2016). Household size is expected to vary directly with expenditure (Oseni et al., 2019b); thus, with increasing household size, farmers tend to divert funds meant for farming to cater for domestic household needs. With good literacy level, farmers' experience in farming is expected to increase the use of technology. The results showed that, averagely $(8.46 \pm 2.54)$, farmers have relatively fair experience for them to have gained mastery of the enterprise. Although about $54 \%$ of the farmers participated and had benefited from cooperative membership, only $48 \%$ had access to quality extension service. The role of cooperatives and extension activities in enhancing management practices and credit access has been detailed (Babalola et al., 2019). Most of the farmers practiced the deep litter system where birds are confined to a house with litter materials on the floor to absorb their faeces/droppings. The rate of ammonia gas volatilization is higher in the deep litter than in the battery cage poultry system since litters stays longer on the farm (Babalola et al., 2015).
About $59 \%$ of the respondents have farm size less than 2,000 birds thus they can be categorized as small-scale poultry farmers (Olorunwa, 2018). Smallscale farmers usually employ crude management practices. Most of the farmers $(75 \%)$ earned less than 100,000 monthly (mean $=61,402 \pm 12,127.17$, approx. \$290) and a good number of them (52\%) have access to credit facility although, up to $48 \%$ still lacked access. The major use of credit among the farming folks was for operational activities $(53 \%)$ which included waste management. Further result showed that most of the respondents $(82 \%)$ were aware of the existence and possible threats from climate change. This result is consistent with past reports (Osuntade and Adebayo, 2019).

\section{Perceived Cause of Climate Change and Faecal Disposal Methods}

The result in Table 2 shows that the respondents perceived that the major causes of climate change, in order of preference, included farming activities (78\%), agro-processing (76\%) and industrial activities (72\%). Despite this perception, Table 3 shows that majority of the farmers used the open dumping method $(80 \%)$ to dispose faecal waste from their farms without any treatment $(50 \%)$. This has a lot of implication on the accumulation and concentration of greenhouse gases in the study environment. Of the three common treatment methods identified, the farmers seem to use alum treatment more $(25 \%)$. Asides accelerating climate change, ammonia emission from poultry manure can cause several problems such as poor birds' performance, reduced birds' immunity capacity, and damaged birds' respiratory systems (Naseem and King, 2018). It may also cause acid precipitation and nitrogen deposition into aquatic systems especially when waste are dumped or eroded into the rivers (Osuntade and Adebayo, 2019). The use of alum (as well as other treatment materials) for treatment reduces the volatilization of ammonia and reduces the number of pathogen in the waste.

Table 2: Respondent-perceived causes of climate change

\begin{tabular}{lc}
\hline Perceived cause & Percentage ('Freq) \\
\hline Farming activities & $77.8(70)$ \\
Industrial activities & $72.2(65)$ \\
Agro-processing & $75.6(68)$ \\
Urbanization & $57.8(52)$ \\
Automobile & $68.9(62)$ \\
Act of God & $22.2(20)$ \\
\hline Source: Field Survey (2018); ${ }^{\dagger}$ existence of multiple response
\end{tabular}

Table 3: Faecal waste disposal and management methods

\begin{tabular}{llll}
\hline${ }^{\prime}$ Disposal methods & $\%($ Freq) & Treatment methods & $\%$ (Freq) \\
\hline Flushing into open gutter & $36.79(33)$ & None & $50.0(45)$ \\
Bagging and stacking & $72.2(65)$ & Alum treatment & $25.5(23)$ \\
Heaping and burning & $65.6(59)$ & Ash treatment & $14.4(13)$ \\
Open dumping & $80.0(72)$ & Ferric chloride treatment & $10.0(9)$ \\
Composting & $7.78(7)$ & & \\
\hline
\end{tabular}




\section{Farmers' Awareness and Limitation for BMP in Faecal Disposal}

Table 4 shows farmers' awareness of all the common BMP for faecal waste disposal. Most of them were aware of composting of the waste $(63 \%)$, use of the waste for biogas production (56\%) and pelleting the waste for fertilizers $(52 \%)$ despite the fact that the respondents were not using these methods of disposal on their farms (Table 3). Consistent with this result, Elenwa and Emodi (2019) also discovered that the use of compost is the least of conservation practices adopted by farmers. Most of the farmers (84\%) claimed that inability to access needed funds was their major limitation for adoption of BMP.

\section{Results of the Determinants of Access to Credit and Best Practices in Faecal Waste Disposal}

The factors that determine poultry farmers' access to credit and use of best management practices (BMP) for faecal waste disposal were captured using the Logit regression. The results are presented in Table 5. The determinants of credit access were farming experience $(p<0.05)$, farm size $(p<0.05)$, awareness of credit source $(\mathrm{p}<0.01)$, cooperative membership $(p<0.05)$, Access to extension service $(p<0.05)$ and farm income $(p<0.05)$.

This implies that increase in these variables will increase the probability of farmers' access to credit. Similar factors were found to influence farmers' access to micro-credit loan scheme in Osun State (Adebisi et al., 2019). In addition, distance of farmers to the credit source $(p<0.05)$ and the system of poultry keeping negatively influenced access to credit meaning that farmers' nearness to credit source and using battery cages for raising birds $(p<0.01)$ will increase the probability of their access to credit.

The descriptive statistics result shows that the farmers had small sized farms; a lot of them had no access to quality extension service and were not involved in cooperative, they had low farm income and practice the deep litter system.

The factors which significantly influenced the use of BMP among poultry farmers for waste disposal were similar to the factors influencing their access to credit which suggest a relationship between the two variables. These explanatory factors included farmers experience $(p<0.05)$, farm size $(p<0.05)$, awareness of credit source $(p<0.05)$, cooperative membership $(p<0.01)$, system of poultry keeping, farm income $(p<0.05)$, access to extension $(p<0.05)$ and credit $(p<0.01)$. All these factors positively influenced use of BMP except farming experience (increasing experience reduced the probability of use of BMP). From this result, access to credit significantly increased the probability of use of BMP in faecal waste management in the study area. This result corroborates the descriptive results for farmers' credit need (Table 1), their perceived limitation to use of BMP (Table 4), and is consistent with Babalola et al. (2015) and Adebisi et al. (2019).

Table 4: Distribution of farmers' by awareness and limitation for BMP

\begin{tabular}{llll}
\hline Variable & $\%($ 'Freq) & Variable & $\%($ Freq) \\
\hline Awareness of BMP: & & Limitations for BMP: & \\
Composting & $63.3(57)$ & Effect on production cost & $50.0(45)$ \\
Biogas production & $55.6(50)$ & Lack of skill & $48.9(44)$ \\
Gasification & $47.8(43)$ & Scale of production & $60.0(54)$ \\
Pelleting for fertilizer & $52.2(47)$ & Lack of awareness & $28.9(26)$ \\
& & Lack access to credit & $84.4(76)$ \\
& & None (current is hygienic) & $17.8(16)$ \\
\hline
\end{tabular}

Source: Field Survey (2018): ${ }^{\dagger}$ existence of multiple response

Table 5: Logit result for determinants of respondents' access to credit and BMP

\begin{tabular}{|c|c|c|c|c|}
\hline \multirow{2}{*}{ Variable(s) } & \multicolumn{2}{|c|}{ Access to credit } & \multicolumn{2}{|c|}{ BMP in faecal disposal } \\
\hline & Coefficient & $\mathrm{t}$-value & Coefficient & t-value \\
\hline Constant & $4.836^{*}$ & 3.401 & $3.870 * *$ & 1.976 \\
\hline Educational level & -0.128 & -1.090 & 0.065 & 1.042 \\
\hline Experience & $0.0591 * *$ & 1.944 & $-0.004 * *$ & -2.037 \\
\hline Farm size & $0.022 * *$ & 2.041 & $0.014 * *$ & 1.932 \\
\hline Awareness of credit & $1.659 *$ & 3.640 & $2.740 * *$ & 2.145 \\
\hline Coop membership & $0.358^{* *}$ & 2.139 & $0.880^{*}$ & 3.509 \\
\hline Extension access & $0.180 * *$ & 1.930 & $0.170^{* *}$ & 1.891 \\
\hline Distance to credit & $-0.190 * *$ & 2.236 & 0.030 & 1.047 \\
\hline Poultry system & $-1.999^{*}$ & -3.242 & $2.290 * *$ & 1.858 \\
\hline Farm income & $0.004 * *$ & 2.024 & $0.327 * *$ & 2.011 \\
\hline Access to credit & - & - & $2.290 *$ & 4.085 \\
\hline -2log likelihood & \multicolumn{2}{|c|}{89.672} & \multicolumn{2}{|c|}{109.818} \\
\hline Nagelkerke $\mathrm{R}^{2}$ & \multicolumn{2}{|c|}{0.630} & \multicolumn{2}{|c|}{0.780} \\
\hline
\end{tabular}

*significant at $1 \%$ level $* *$ significant at 5\% level

Source: Computed from field data (2018) 


\section{CONCLUSION AND RECOMMENDATIONS}

This study evaluated the socio-economic characteristics determining poultry farmers' access to credit and best management practices (BMP) and further analyzed the influence of access to credit on management practices among poultry farmers in Obafemi Owode Local Government Area of Ogun State, Nigeria. Farming experience, farm size, awareness of credit source, cooperative participation, access to extension service and farm income were associated with both access to credit and farmers' use of appropriate waste management practice. Also, credit access significantly influenced BMP. The study also assessed sources of credit available to farmers in the area and also some constraints encountered in accessing credit facility. Based on the findings in this research, the following are recommended:

1. Managing waste should not be left to farmers' individual convenience. While facilitating farmers' access to needed funds for adopting best management practices in poultry faecal disposal, appropriate policies enhancing farmers' compliance should be put in place.

2. Government credit agencies, project and commercial banks should work more with cooperative societies in making credit access easier for cooperative members.

3. Improving extension services to guide and educate poultry farmers to improve their awareness of credit source in the study area which has a significant effect on access to credit.

4. Ensuring the participation of poultry farmers in co-operatives to enhance their access to credit and hence, encourage better management practices.

\section{REFERENCES}

Adebisi L.O., Jimoh O., Jonathan A., Osasona K.K. and Ojediran E.O. (2019). Determinant of farmers' participation and repayment of Osun rural enterprise and agricultural Program (OREAP) micro-credit loan scheme. Agro-Science, 18 (2), 15-19

Adejuwon J.O. and Ogundiminegha Y.G. (2019). Impact of climate variability on cassava yield in the humid forest agro-ecological zone of Nigeria. J. Appl. Sci. Environ. Manage., 23 (5), 903-908

Adeyonu A.G. (2015). Determinants of loan repayment among small holder cooperative farmers in Remo Division, Ogun State, Nigeria. J. Agr. Sci., 8 (1), 92-99

Aiyelokun O. and Odekoya O. (2016). Analysis of trend and variability of atmospheric temperature in Ijebu-Ode, Southwest Nigeria. Afr. J. Geo-Sci. Res., 4 (2), 09-12

Babalola D.A., Isitor S.U. and Kio J.O. (2015). Composted poultry waste use intensity among arable farmers in Ogun State, Nigeria: Implication for climate change. Brit. J. Appl. Sci. Technol., 12 (1), 1-7

Babalola D.A., Osuntade B.O., Kio J.O. and Agbede C.O. (2019). Economic burden of malaria and productivity of farmers in Nigeria: Evidence from Ogun State. $J$. Applied Sci. Res., 6 (4), 113

Baruwa O. and Omodara D. (2018). Poultry waste management practices and policy implications for environmental sustainability in urban areas of Osun State, Nigeria. Applied Trop. Agric., 23 (1), 25-34
Chioma G., Afodu O., Akinboye F., Ndubuisi-Ogbonna L. and Ogunnowo D. (2017). Impact of access to credit on poultry farmer's performance in Ikenne Local Government Area of Ogun State, Nigeria. J. Agric. Econ. Dev., 6 (6), 050-055

Elenwa C.O. and Emodi A.I. (2019). Soil conservation practices among rural farmers in arable crop production in Omuma Local Government Area of Rivers State, Nigeria. Agro-Science, 18 (3), $42-47$

Gujarati D.N. (1998). Basic Econometrics. McGraw Hill, New York, pp. 98-102

Heise H., Crisan A. and Theuvsen L. (2015). The poultry market in Nigeria: Market structures and potential for investment in the market. Int. Food Agribusiness Manage. Rev., 18 (1), 197-222

IPCC (2019). Final Government Distribution. Intergovernmental Panel on Climate Change (IPCC). https://www. ipcc.ch/site/assets/uploads/2019/08/2f.-Chapter-5_FINAL.pdf

Isitor S.U., Babalola D.A. and Obaniyi K.S. (2014). An analysis of credit utilization and farm income of arable crop farmers in Kwara State, Nigeria. Global J. Sci. Frontier Res., 14 (10), 1-10

Jatto N.A., Obalola T.O., Shettima B.A. and Okebiorun E.O. (2019). Reasons for delay in repayment of agricultural loan by farmers in Kwara State, Nigeria. Asian J. Agric. Ext., Econ. Sociol., 31 (2), 1-4

McAllister J. (2015). Factors Influencing Solid-Waste Management in the Developing World, All Graduate Plan B and other Reports 528. Utah State University, Logan, Utah, 20-75

Musa I.W. and Kaltungo B.Y. (2017). Poultry Litter Selection, Management and Utilization in the Tropics. Retrieved from https://www.intechopen.com/books/ poultry-science/poultry-litter-selection-managementand-utilization-in-the-tropics

Naseem S. and King A.J. (2018). Ammonia production in poultry houses can affect health of humans, birds, and the environment - techniques for its reduction during poultry production. Environ. Sci. Pollut. Res., 25, 15269-15293

NBS (2016). National Bureau of Statistics, Nigeria General Household Survey-Panel Wave 3 (Post Planting) 2015-2016, Third round. Retrieved from https://www.nigerianstat.gov.ng/nada/index.php/catalog/51

Olorunwa O.J. (2018). Economic analysis of broiler production in Lagos State Poultry Estate, Nigeria. $J$. Invest. Manage., 7 (1), 35-44

Onu D.O., Offor E.I. and Okpara B.O. (2015). Poultry wastes management strategies and environmental implications in Abia State. Int. Res. J. Agric. Sci. Soil Sci., 5 (6), 159-164

Oseni I.O., Babalola D.A. and Adesoye B.A. (2019a). Agricultural credit policy as a panacea for sustainable food production in Nigeria: Evidence from Ogun State. SPOUDAI J. Econ. Business, 69 (1-2), 18-29

Oseni I.O., Okwu A.T., Babalola D.A. and Adegboyega S.B. (2019b). Recession and the challenge of sustainable economic growth in Nigeria: An evaluation of macroeconomic policies. Tanzanian Econ. Rev., 9 (1), 93-112

Osinowo O.H. and Tolorunju, E.T. (2019). Technical efficiency of poultry egg production in Ogun State, Nigeria. J. Agribus. Rural Dev., 1 (51), 51-58

Osuntade O.B. and Adebayo K. (2019). Intensive chicken management practices: A trajectory to environmental issues in Southwest Nigeria. Proc. 28 $8^{\text {th }}$ Annual National Congr. Rural Sociological Assoc. of Nigeria (pp. 159-161), Obafemi Awolowo University. Retrieved from http://rusan.org.ng/conference

Sahel Capital (2015). An Assessment of the Nigerian Poultry Sector (No. 11). Lagos, Nigeria. Retrieved from http://www.sahelcp.com 